\author{
UDC 669.141.24:539.431.015
}

\author{
I. A. VAKULENKO ${ }^{1 *}$, S. V. PROYDAK ${ }^{1}$ \\ ${ }^{1 *}$ Dep. «Materials Technology», Dnipropetrovsk National University of Railway Transport named after Academician \\ V. Lazaryan, Lazaryan St., 2, Dnipropetrovsk, Ukraine, 49010, tel. +38 (056) 373 15 56, e-mail dnyzt texmat@ukr.net \\ ${ }^{1}$ Dep. «Materials Technology», Dnipropetrovsk National University of Railway Transport named after Academician \\ V. Lazaryan, Lazaryan St., 2, Dnipropetrovsk, Ukraine, 49010, tel. +38 (056) 373 15 56, e-mail dnyzt texmat@ukr.net
}

\title{
THE INFLUENCE MECHANISM OF FERRITE GRAIN SIZE ON STRENGTH STRESS AT THE FATIGUE OF LOW-CARBON STEEL
}

Purpose. Explanation of the influence mechanism of ferrite grain size on the fatigue strength of low-carbon steel. Methodology. Material for research is the low-carbon steel with $0.1 \%$ of carbon contnent. The different size of ferrite grain was obtained due to varying the degree of cold plastic deformation and temperature of annealing. The estimation of grain size was conducted using methodologies of quantitative metallography. The microstructure of metal was investigated under a light microscope with increase up to 1500 times. As a fatigue response the fatigue strength of metal - a maximal value of load amplitude with endless endurance limit of specimen was used. Fatigue tests were carried out using the test machine «Saturn-10», at the symmetric cycle of alternating bend loading. Findings. On the basis of research the dependence for fatigue strength of low-carbon steel, which is based on an additive contribution from hardening of solid solution by the atoms of carbon, boundary of the ferrite grain and amount of mobile dislocations was obtained. It was established that as the grainy structure of low-carbon steel enlarges, the influence of grain size on the fatigue strength level is reduced. For the sizes of grains more than $100 \mathrm{mcm}$, basic influence on fatigue strength begins to pass to the solid solution hardening, which is determined by the state of solid solution of introduction. Originality. From the analysis of the obtained dependences it ensues that with the increase of ferrite grain size the required amount of mobile dislocations for maintenance of conditions for spreading plastic deformation becomes less dependent from the scheme of metal loading. Practical value. The obtained results present certain practical interest when developing of recommendations, directed on the increase of resource of products work from low-carbon steels in the conditions of cyclic loading. Estimation of separate contribution of the studied processes of structural changes with fatigue load allows one to choose a rational solution - to use the hardening effect from the ferrite alloying or to change the grain size of ferrite.

Keywords: ferrite; grain size; fatigue strength; solid solution; carbon

\section{Introduction}

In the process of loading the ferrite grain size determines most of the properties of single-phase alloys and carbon steels [1]. Gradual accumulation of defects in crystalline structure and their localization during cyclic loading can lead (in certain microvolumes of metallic material) to the forming of the breakdown sites, as in the case of unidirectional static deformation.
Taking into account the heterogeneity of strain distribution, especially in the initial stages of plastic flow of unidirectional loading in the metal volumes near to the grain boundaries will increasingly occur the processes of accumulation of crystal structure defects.

Under cyclic loading the magnitude of cycle deformation, the temperature [2] and the dislocations ability to nonconservative movement [3] will to some extent determine the processes, which cause 
the metal hardening. In this case, the rate of dislocations accumulation and the beginning of formation of substructure units, such as fragment walls and dislocation cellular structure in some ferrites, which are favorably oriented with respect to the actual stresses, can be considered as the beginning of the incubation period of the metal destruction process.

One of the known mechanisms explaining the process of microcrack initiation [10] is based on the initiation of breakdown site resulting from the step forming in the place of slip band emergence on the sample surface under the cyclic loading. Subsequent recombination of dislocations leads to the irreversible deformations in the specified place on the metal surface. Therefore, it is safe to assume that the gradual accumulation to the maximum permissible concentration of structural defects near the steps, is one of the main reasons leading to the microcracks initiation and the subsequent loading conditions determine the rate of its growth.

There is a sufficient quantity of the experimental results, which indicate the dependence of fatigue processes development in the metal materials from the grain size. This situation is often caused by the lack of accounting of structural change processes in the metal internal structure under cyclic loading, as compared to the conditions of static unidirectional deformation.

\section{Purpose}

The work purpose is to explain the influence mechanism of ferrite grain size on the fatigue strength of low-carbon steel.

\section{Methodology}

Material for research was the low-carbon steel with $0.1 \%$ of carbon content. The different size of ferrite grain was obtained due to varying the degree of cold plastic deformation and temperature of annealing. The estimation of grain size was conducted using methodologies of quantitative metallography [4]. The microstructure of metal was investigated under a light microscope with increase up to 1500 times. As a fatigue response the maximum value of load amplitude $\left(\sigma_{-1}\right)$ when reaching the conditions of unlimited specimen endurance was used. Fatigue tests were carried out using the test machine «Saturn-10», at the symmetric cycle of alternating bend loading.

\section{Findings}

Behavior analysis of the single-phase alloys under loading showed that only in some cases the polycrystalline strength according to absolute values is approaching to the quarter of the theoretical strength of a perfect crystal $[1,10]$. On the other hand, the strength property level of metal in the grain boundaries reaches the values of the same order with the metal within grains [14]. On the basis of above mentioned, the origin and distribution of dislocations according to crystallographic slip systems, could be the determining factor during metal loading in the region of small plastic deformations. Moreover, the internal structure of the grain boundary itself and the inevitable presence of impurity atoms of implementation can make a definite contribution to the changing nature of the grain size influence.

Conditions of unidirectional static loading the reduction of the grain size of the low-carbon steel is accompanied by the increase in resistance value of microplastic deformation $\left(\sigma_{0}\right)$, which is the part of the deformation curve equation [15]:

$$
\sigma=\sigma_{0}+K \varepsilon^{m}
$$

where $K-$ is the constant value, $\varepsilon-$ is true strain, $m-$ is power index. As the yield stress $\left(\sigma_{T}\right)$ the value $\sigma_{0}$ obeys to the Hall-Petch dependence [5] (Fig. 1):

$$
\sigma_{0}=\sigma_{i}+k_{y} d^{-\frac{1}{2}}
$$

$$
\sigma_{0}, \mathrm{MPa}
$$

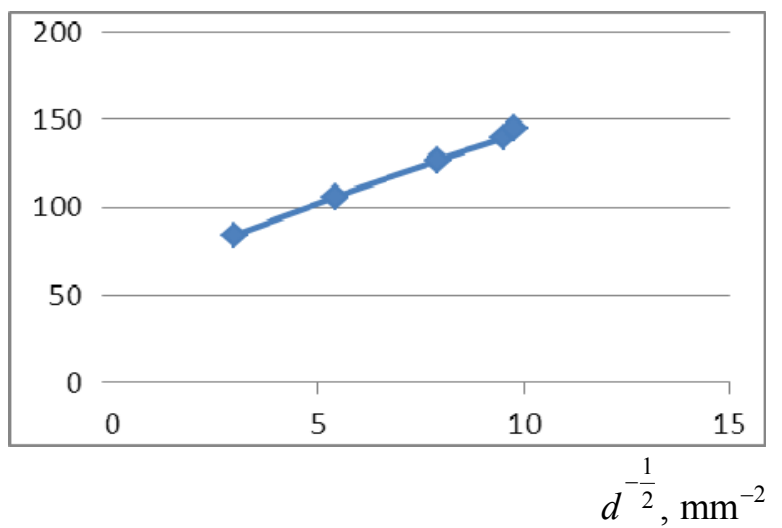

Fig. 1. Execution of the relation (2) for the value $\sigma_{0}$ of low-carbon steel 
where $\sigma_{i}-$ is the friction stress of ferrite crystalline lattice, value $k_{y}$-determines the influence of grain boundaries, $d-$ is the ferrite grain size.

Taking into account that in the initial stages of cyclic loading of dislocation displacement one is limited by the volume of ferrite grain of lowcarbon steel, the state of solid solution should have some influence (if not the main one) on the process of microcracks initiation. On the other hand, the end of the incubation stage of microcrack growth is most often associated with the intersection of the first angular grain boundary $[3,10]$. On the basis of the above mentioned, starting from the specified moment (the accelerated growth stage) the process of fatigue crack propagation becomes dependent on the presence of the ferrite grain boundaries [17].

As a result of cyclic loading of the investigated steel with different ferrite grain size the fatigue strength values $\left(\sigma_{-1}\right)$ were obtained. Dependence $\sigma_{-1}=f\left(d^{-\frac{1}{2}}\right)$ is shown in Fig. 2.

According to external characters the change $\sigma_{-1}$ from ferrite grain size (Fig. 2) is subject to a similar dependence (2):

$$
\sigma_{-1}=\sigma_{i}^{\prime}+k_{y}^{\prime} d^{-\frac{1}{2}}
$$

where $\sigma_{i}^{\prime}$ and $k_{y}^{\prime}$ are the constants, similar to the corresponding characteristics of equation (2).

$$
\sigma_{-1}, \mathrm{MPa}
$$

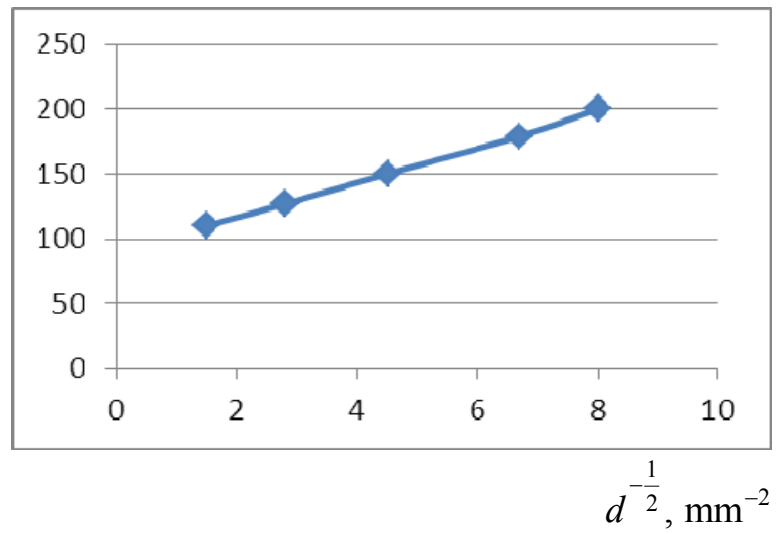

Fig. 2. Dependence $\sigma_{-1}$ on the ferrite grain size of low-carbon steel

As a result, the graphical solution of the equation $\sigma_{-1}=f\left(d^{-\frac{1}{2}}\right)$ the values $\sigma_{i}^{\prime}$ and $k_{y}^{\prime}$ were ob- tained, which are respectively equal to $90 \mathrm{MPa}$ and $12.5 \mathrm{~N} / \mathrm{mm}^{3 / 2}$. Taking into account that the stress $\sigma_{i}^{\prime}$ naturally should characterize the resistance to dislocation displacement within the ferrite grain (friction stress of the crystalline lattice), the level $90 \mathrm{MPa}$ is much higher than the known values of the specified characteristics. Indeed, according to numerous studies $[1,10,12,16]$, the friction stress of the iron crystalline lattice is $8-17 \mathrm{MPa}$, and taking into account that the ferrite is a solid interstitial solution the body-centered cubic lattice of the iron contains about 12MPa of carbon atoms [5].

For the conditions of unidirectional loading of investigated steel values of the equation constants (2) were determined. They are correspondingly equaled: $\sigma_{i}=50 \mathrm{MPa}$ and $k_{y}=10 \mathrm{~N} / \mathrm{mm}^{\frac{3}{2}}$ (Fig. 1). Comparative analysis of the obtained characteristics shows that for $\sigma_{i}$ the difference is $38 \mathrm{MPa}$, which is explained by the hardening effects because of the presence of a certain concentration of carbon atoms in the ferrite lattice $[1,2]$.

Under cyclic loading, the specified difference is equaled to $78 \mathrm{MPa}(90 \mathrm{MPa}-12 \mathrm{MPa})$. Thus, the observed increase of the magnitude $\sigma_{i}^{\prime}$ during fatigue can be first of all associated with more efficient blocking of reciprocating dislocations by carbon atoms. Confirmation of this phenomenon may be possibility increase of multiple dislocation slip on different crystallographic systems. For the crystalline lattice of body-centered cubic type the dislocation displacement is possible according to three crystallographic slip systems $\{110\},\{112)$ and $\{123\}$, at $<111>$ [9]. On the basis of the above mentioned it is safe to assume that under cyclic loading of low carbon steel, the reversible dislocation displacement is accompanied not only by annihilation, but also by the transition into the other slip systems $[1,13]$. In this case, the possibility of dislocations blocking by carbon atoms should increase. Consequently, the value $\sigma_{i}^{\prime}$ can be written as:

$$
\sigma_{i}^{\prime}=\sigma_{i}+\Delta,
$$

where $\Delta-$ is the value of solid-solution ferrite strengthening in reverse loading.

Another characteristic $-k_{y}^{\prime}$ to a lesser extent differs from the value $k_{y}$, which once again points to the role of influence of the ferrite grain bounda- 
ries on the development of fatigue fracture of lowcarbon steel.

After conversion of ratio (3) similar to that performed for (2) [2], it becomes possible to evaluate the stress $\left(\sigma_{1}\right)$ required for dislocation displacement from their source to the grain boundaries:

$$
\sigma_{1}=\frac{k_{y}^{\prime}}{2 \sqrt{l}}
$$

where $l-$ is the distance of dislocations source from the ferrite grain boundaries. Considering that $l$ in general can take values from 0 (the source of dislocations are the angular ferrite grain boundaries $[1,2])$ to $l=d$ (intragranular source location), we take the average value $l=\frac{d}{2}$.

Then the ratio (5) should be rewritten:

$$
\sigma_{1}=\frac{k_{y}^{\prime}}{\sqrt{2 d}}
$$

During the formal application of the values $\sigma_{1}$ calculated according to (6), for the same values $d$ against the corresponding values $\sigma_{-1}$ it is found out an unambiguous relationship with a sufficiently high correlation coefficient (Fig. 3).

Analysis of absolute values shows that the value $\sigma_{1}$ several times less than $\sigma_{-1}$. At the same time, the rougher grain structure of the metal, the greater the difference between these characteristics.

Considering the total contribution to the value $\sigma_{-1}$ from $\sigma_{i}, \Delta$ and $\sigma_{1}$, the difference should be atributed to the metal hardening from the

$$
\sigma_{1}, \mathrm{MPa}
$$

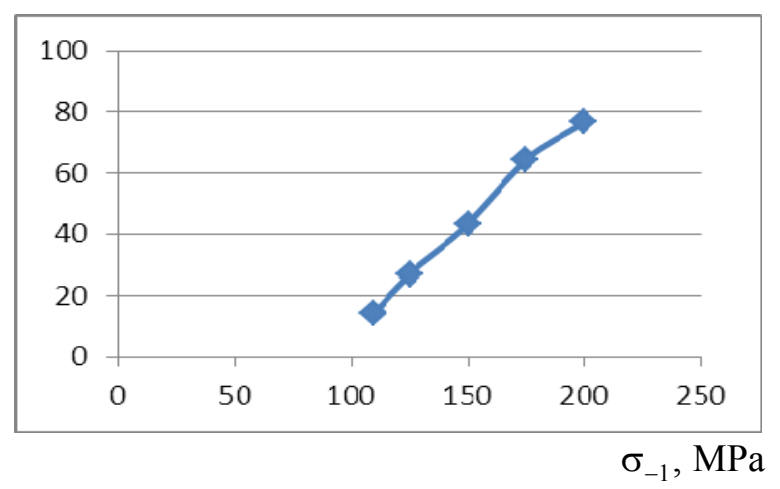

Fig. 3. Mutual change of $\sigma_{1}$ and $\sigma_{-1}$ interaction of mobile dislocations with the blocked by carbon atoms dislocations $\left(\sigma_{2}\right)$. Changing $\sigma_{2}$ from the ferrite grain size is represented in Fig. 4.

Based on this dependence (Fig. 4), one can estimate the value $\sigma_{2}$ using the well-known relation [13]:

$$
\sigma_{2}=\alpha \mu b \sqrt{\rho},
$$

where $\alpha-$ is a coefficient, which takes the values from 0.1 to $1.0, \mu$ - is the shear modulus, $b-$ is the Burgers vector and $\rho-$ is the density of mobile dislocations.

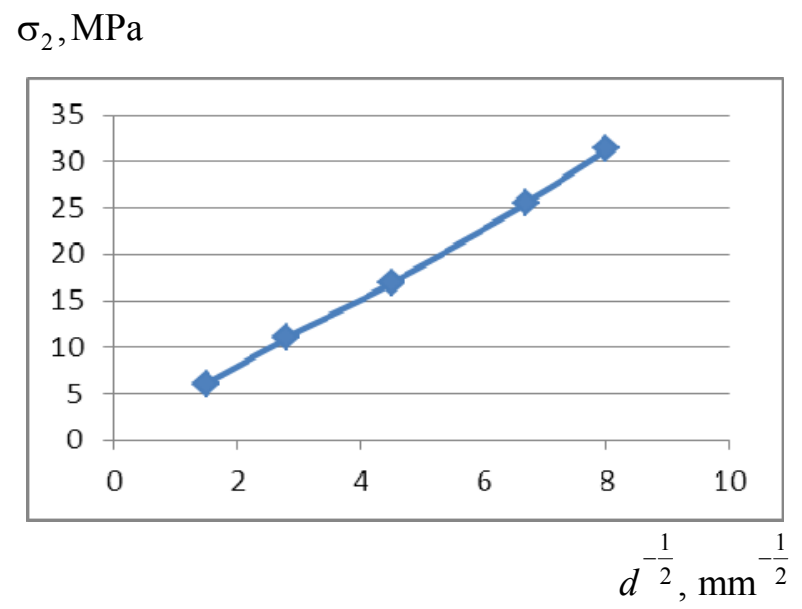

Fig. 4. Influence of ferrite grain size on the value $\sigma_{2}$

Considering the observed components in general terms the value of the fatigue strength of lowcarbon steel may be written as:

$$
\sigma_{-1}=\sigma_{i}+\Delta+\frac{k_{y}^{\prime}}{\sqrt{2 d}}+\alpha \mu b \sqrt{\rho}
$$

After substitution into (8) of $\alpha=0.6$ (the average value of interval $0.1-1.0$ ), $\mu=8.2 \cdot 10^{4} \mathrm{MPa}$ (for carbon steel), $b=2.48 \cdot 10^{-7} \mathrm{~mm}$ (for ferrite), the experimental values $\sigma_{-1}, \sigma_{i}$ and $\Delta$ the values $\rho$ were calculated.

The obtained values $\rho$ represent the density of mobile dislocations, which is necessary for maintaining the conditions of plastic deformation propagation for a loading cycle. Fig. 5 shows the dependence of this characteristic $(\rho)$ from the ferrite grain size of low-carbon steel under cyclic loading. 
$\rho, \times 10^{5} \mathrm{~mm}^{-2}$

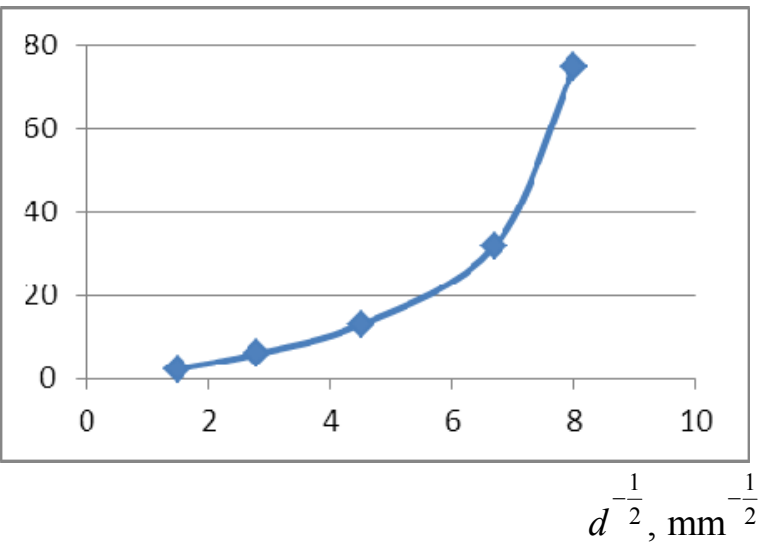

Fig. 5. Influence of ferrite grain size on $\rho$ of low-carbon steel

Comparative analysis of $\rho$ with similar characteristics of investigated steel (Fig. 6) for the conditions of static strain $\left(\rho_{1}\right)$ showed that as the size of ferrite grain increases the difference between them decreases. Thus, for the ferrite grain size $d=$ 15.6-16mcm: $\rho=7.5 \cdot 10^{6} \mathrm{~mm}^{-2}, \quad \rho_{1}=10^{7} \mathrm{~mm}^{-2}$; for $d=22-24 \mathrm{mcm}: \quad \rho=2.9 \cdot 10^{6} \mathrm{~mm}^{-2}$, $\rho_{1}=4 \cdot 10^{6} \mathrm{~mm}^{-2}$ and for $d=115-120 \mathrm{mcm}$ : $\rho=4.4 \cdot 10^{5} \mathrm{~mm}^{-2}, \rho_{1}=4.2 \cdot 10^{5} \mathrm{~mm}^{-2}$.

$\rho_{1}, \times 10^{6} \mathrm{~mm}^{-2}$

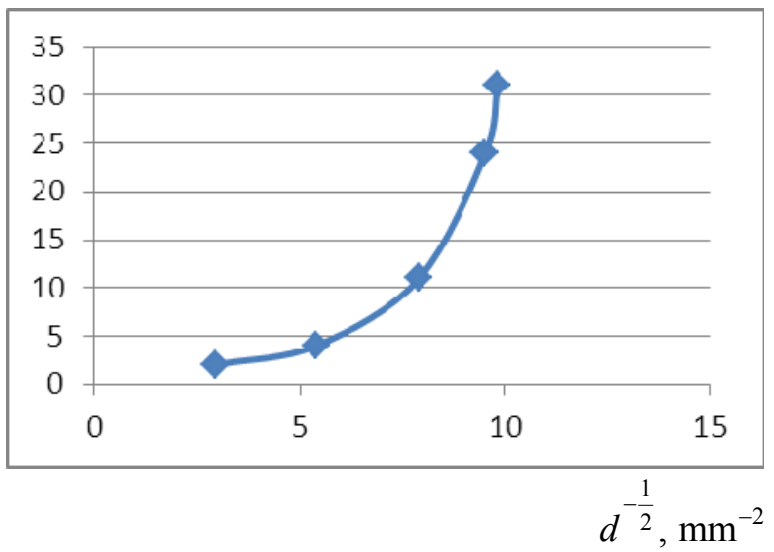

Fig. 6. Influence of ferrite grain size on $\rho_{1}$ of low-carbon steel

The obtained results show that with increase of ferrite grain size the required amount of mobile dislocations, to maintain the conditions of propagation of plastic deformation becomes less dependent on metal loading scheme. Analysis of the equation is the confirmation of the above mentioned (8). Thus, as the grain structure of the low carbon steel coarsens the influence of grain size on the level of the fatigue strength decreases. For the grain sizes greater than $100 \mathrm{mcm}$, the main influence on the values $\sigma_{-1}$ transits to the solid solution hardening, that is determined by the concentration of carbon atoms in the ferrite, i.e. by the value $\sigma_{i}^{\prime}$ from the ratio (4).

\section{Originality and practical value}

The analysis of obtained dependencies shows that as the ferrite grain size increases the required amount of mobile dislocations to maintain the conditions of plastic deformation propagation becomes less dependent on the metal loading scheme. The obtained results are of particular interest in the development of practical recommendations aimed at improving the operation life of the products of low-carbon steels under cyclic loading. Evaluation of separate contribution of structural components at certain stages of fatigue loading development, allows one to choose a rational solution - to use the hardening effect of changes in the state of solid solution of low-carbon steel or vary ferrite grain size.

\section{Conclusions}

1. The analysis shows that the level of fatigue strength of low-carbon steel is determined by the additive contribution from the condition of solid solution, ferrite grain size and hardening, caused by the interaction of blocked and mobile dislocations.

2. As the ferrite grain size increases the required amount of mobile dislocations to maintain the conditions of plastic deformation propagation becomes less dependent on the metal loading scheme.

3. Coarsening of the ferrite structure is accompanied by decrease in the contribution of grain boundaries and increase of the role of solid solution hardening in improving fatigue strength. 


\section{LIST OF REFERENCE LINKS}

1. Бабич, В. К. Деформационное старение стали / В. К. Бабич, Ю. П. Гуль, И. Е. Долженков. М. : Металлургия, 1972. - 320 с.

2. Вакуленко, И. А. Морфология структуры и деформационное упрочнение стали / И. А. Вакуленко, В. И. Большаков. - Д. : Маковецкий, 2008. - $196 \mathrm{c}$.

3. Вакуленко, И. А. Структура и свойства углеродистой стали при знакопеременном деформировании / И. А. Вакуленко. - Д. : Gaudeamus, 2003. - 94 c.

4. Вакуленко, І. О. Структурний аналіз в матеріалознавстві / І. О. Вакуленко. - Д. : Маковецький, 2010. - 124 с.

5. Вакуленко, И. А. О связи величины $\sigma_{0}$ кривой деформации с параметрами уравнения Холла Петча / И. А. Вакуленко, В. А. Пирогов, В. К. Бабич // Металлофизика. - 1986. - Т. 8, № 6. - С. 61-64.

6. Вакуленко, I. О. Про взаємозв'язок структурних перетворень при втомі вуглецевої сталі 3 особливостями будови поверхонь руйнування / І. О. Вакуленко // Вісн. Дніпропетр. нац. ун-ту залізн. трансп. - Д., 2010. - Вип. 32. C. 242-245.

7. Вакуленко, I. О. Аналіз діаграм циклічного навантаження металевих матеріалів / I. О. Вакуленко // Вісн. Дніпропетр. нац. ун-ту залізн. трансп. - Д., 2009. - Вип. 26. - С. 163-165.

8. Вакуленко, І. О. Дослідження етапів зародження та зростання тріщин при натурному випробуванні на втомленість / I. О Вакуленко, М. А. Грищенко, О. М. Перков // Вісн.
Дніпропетр. нац. ун-ту залізн. трансп. - Д., 2008. - Вип. 21. - С. 266-268.

9. Коттрелл, А. Х. Дислокации и пластическое течение в кристаллах / А. Х. Коттрелл. - М. : Металлургиздат, 1958. - 255 с.

10. Нотт, Дж. Ф. Основы механики разрушения / Дж. Ф Нотт. - М. : Металлургия, 1978. - 256 с.

11. Atkinson, J. D. The Work - hardening of Copper Silica: IV. The Bauschinger Effect and Plastic Relaxation / J. D. Atkinson, L. M. Brown, W. B. Stobs // Philosophical Magazine. - 1974. Vol. 30, № 6. - P. 1247-1280.

12. Crist, B. W. Comparison of the Hall - Petch parameters of Zone - refined Iron Determined by the Grain Size and Extrapolation Methods / B. W. Crist, C. V. Smith // Acta Metallurgica. 1967. - Vol. 15, № 5. - P. 809-816.

13. Garofalo, F. Factors Affecting the Propagation of a Luders Band and the Lower Yield and Flow Stressers / F. Garofalo // Metallurgical Transactions. - 1971. - Vol. 2, № 8. - P. 2315-2317.

14. Gleiter, H. High - Grain Boundaries / H. Gleiter, B. Chalmers // Progress in Materials Science. 1972. - Vol. 16. - 375 p.

15. Hollomon, John H. Tensile Deformation / John H. Hollomon // AIME. -1945. - Vol. 162. P. 268-290.

16. Holzman, M. Determination of Friction stress in BCC polycristalls / M. Holzman, J. Man // J. of the Iron and Steel Inst. - 1966. - Vol. 204, № 3. - P. 230-234.

17. Vakulenko, I. A Mechanism of the Effect of the Ferrite Grain Size on the Fatigue Strength of a Low - Carbon Steel / I. A. Vakulenko, O. N. Perkov, V. G. Razdobreev // Russian Metallurgy. - 2008. - № 3. - P. 225-228.

\section{И. А. ВАКУЛЕНКО ${ }^{1 *}$, С. В. ПРОЙДАК ${ }^{1}$}

\footnotetext{
${ }^{1 *}$ Каф. «Технология материалов», Днепропетровский национальный университет железнодорожного транспорта имени академика В. Лазаряна, ул. Лазаряна, 2, Днепропетровск, Украина, 49010, тел. +38 (056) 3731556 , эл. почта dnyzt texmat@ukr.net

${ }^{1}$ Каф. «Технология материалов», Днепропетровский национальный университет железнодорожного транспорта имени академика В. Лазаряна, ул. Лазаряна, 2, Днепропетровск, Украина, 49010, тел. +38 (056) 3731556 , эл. почта dnyzt texmat@ukr.net
}

\section{МЕХАНИЗМ ВЛИЯНИЯ РАЗМЕРА ЗЕРНА ФЕРРИТА НА УСТАЛОСТНУЮ ПРОЧНОСТЬ НИЗКОУГЛЕРОДИСТОЙ СТАЛИ}

Цель. Объяснение механизма влияния размера зерна феррита на усталостную прочность низкоуглеродистой стали. Методика. Материалом для исследования служила низкоуглеродистая сталь с содержанием углерода $0,1 \%$. Различный размер зерна феррита получали за счет варьирования степенью холодной пластической деформации и температурой отжига. Оценку величины зерна проводили, используя методики количественной металлографии. Микроструктуру металла исследовали под световым микроскопом при увеличениях до 1500 раз. В качестве характеристики усталости использовали усталостную прочность металла - 
максимальное значение амплитуды нагружения при бесконечной выносливости образца. Испытания на усталость осуществляли на испытательной машине «Сатурн-10» при симметричном цикле знакопеременного нагружения изгибом. Результаты. На основе проведенных исследований получена зависимость для усталостной прочности низкоуглеродистой стали, которая основана на аддитивном вкладе от упрочнения твердого раствора атомами углерода, границ зерна феррита и количества подвижных дислокаций. В работе установлено, что по мере укрупнения зернистой структуры низкоуглеродистой стали влияние размера зерна на уровень усталостной прочности снижается. При размерах зерен более 100 мкм основное влияние на усталостную прочность начинает переходить к твердо растворному упрочнению, определяемому состоянием твердого раствора внедрения. Научная новизна. Из анализа полученных зависимостей следует, что с ростом размера зерна феррита требуемое количество подвижных дислокаций для поддержания условий распространения пластической деформации становится в меньшей степени зависимым от схемы нагружения металла. Практическая значимость. Полученные результаты представляют практический интерес при разработке рекомендаций, направленных на повышение ресурса работы изделий с низкоуглеродистой стали в условиях циклического нагружения. Оценка раздельного вклада от рассмотренных процессов структурных изменений на определенных этапах развития усталостного нагружения позволит выбрать оптимальное решение - использовать эффект упрочнения от легирования феррита либо уменьшить размер его зерна.

Ключевые слова: феррит; размер зерна; усталостная прочность; твердый раствор; углерод

\title{
I. О. ВАКУЛЕНКО ${ }^{1 *}$, С. В. ПРОЙДАК ${ }^{1}$
}

\author{
${ }^{1 *}$ Каф. «Технологія матеріалів», Дніпропетровський національний університет залізничного транспорту \\ імені академіка В. Лазаряна, вул. Лазаряна, 2, Дніпропетровськ, Україна, 49010, тел. +38 (056) 37315 56, \\ ел. пошта dnyzt_texmat@ukr.net \\ ${ }^{1}$ Каф. «Технологія матеріалів», Дніпропетровський національний університет залізничного транспорту \\ імені академіка В. Лазаряна, вул. Лазаряна, 2, Дніпропетровськ, Україна, 49010, тел. +38 (056) 37315 56, \\ ел. пошта dnyzt_texmat@ukr.net
}

\section{МЕХАНІЗМ ВПЛИВУ РОЗМІРУ ЗЕРНА ФЕРИТУ НА МІЦНСТЬ ПРИ ВТОМІ НИЗЬКОВУГЛЕЦЕВОЇ СТАЛІ}

Мета. Пояснення механізму впливу розміру зерна фериту на міцність при втомі низько вуглецевої сталі. Методика. Матеріалом для дослідження слугувала низько вуглецева сталь із вмістом вуглецю $0,1 \%$. Різний розмір зерна фериту отримували за рахунок варіювання ступенем холодної пластичної деформації й температурою відпалу. Оцінку величини зерна проводили, використовуючи методики кількісної металографії. Мікроструктуру металу досліджували під світловим мікроскопом при збільшеннях до 1500 разів. В якості характеристики втоми використовували межу міцності при втомі металу - максимальне значення амплітуди навантаження при необмеженій витривалості зразку. Випробування на втому здійснювали на випробувальній машині «Сатурн-10» при симетричному циклі знакозмінного навантаження вигином. Результати. На основі проведених досліджень отримана залежність для межі міцності при втомі низьковуглецевої сталі, яка заснована на адитивному вкладі від зміцнення твердого розчину атомами вуглецю, меж зерна фериту й кількості рухливих дислокацій. У роботі встановлено, що в міру укрупнення зернистої структури низьковуглецевої сталі вплив розміру зерна на рівень межі міцності при втомі знижується. При розмірі зерен більше 100 мкм основний вплив на міцність при втомі починає переходити до твердо розчинного зміцнення, що визначається станом твердого розчину впровадження. Наукова новизна. 3 аналізу отриманих залежностей випливає, що зі збільшенням розміру зерна фериту необхідна кількість рухливих дислокацій для підтримки умов поширення пластичної деформації стає меншою мірою залежною від схеми навантаження металу. Практична значимість. Отримані результати становлять певний практичний інтерес при розробці рекомендацій, які спрямовані на підвищення ресурсу роботи виробів із низьковуглецевих сталей в умовах циклічного навантаження. Оцінка роздільного внеску від розглянутих процесів структурних змін на певних етапах розвитку втомного навантаження дозволить обрати оптимальне рішення - використовувати ефект зміцнення від легування фериту або зменшити розмір його зерна.

Ключові слова: ферит; розмір зерна; міцність при втомі; твердий розчин; вуглець 


\section{REFERENCES}

1. Babich V.K., Gul Yu.P., Dolzhenkov I.Ye. Deformatsionnoye stareniye stali [Strain aging of the steel]. Moscow, Metallurgiya Publ., 1972. 320 p.

2. Vakulenko I.A., Bolshakov V.I. Morfologiya struktury i deformatsionnoye uprochneniye stali [Structure morphology and strain hardening steel]. Dnipropetrovsk, Makovetskiy Publ., 2008. 196 p.

3. Vakulenko I.A. Struktura i svoystva uglerodistoy stali pri znakoperemennom deformirovanii [Structure and properties of the carbon steel during the alternating deformation]. Dnipropetrovsk, Gaudeamus Publ., 2003. 94 p.

4. Vakulenko I.O. Strukturnyi analiz v materialoznavstvi [Structural analysis in the material science]. Dnipropetrovsk, Makovetskyi Publ., 2010. 124 p.

5. Vakulenko I.A., Pirogov V.A., Babich V.K. O svyazi velichiny $\sigma_{0}$ krivoy deformatsii s parametrami uravneniya Kholla - Petcha [On the relationship between the value $\sigma_{0} \mathrm{f}$ the deformation curve with the parameters of the Hall - Petch equation]. Metallofizika - Metallophysics, 1986, vol. 8, no. 6, pp. 61-64.

6. Vakulenko I.O. Pro vzaiemozviazok strukturnykh peretvoren pry vtomi vuhletsevoi stali z osoblyvostiamy budovy poverkhon ruinuvannia [On the relationship of structural changes at fatigue of carbon steel with structural features of the fracture surfaces]. Visnyk Dnipropetrovskoho natsionalnoho universytetu zaliznychnoho transportu [Bulletin of Dnipropetrovsk National University of Railway Transport], 2010, issue 32, pp. 242-245.

7. Vakulenko I.O. Analiz diahram tsyklichnoho navantazhennia metalevykh materialiv [Analysis of diagrams of cyclic loading for metallic materials]. Visnyk Dnipropetrovskoho natsionalnoho universytetu zaliznychnoho transportu [Bulletin of Dnipropetrovsk National University of Railway Transport], 2009, issue 26, 163-165 pp.

8. Vakulenko I.O., Hryshchenko M.A., Perkov O.M. Doslidzhennia etapiv zarodzhennia ta zrostannia trishchyn pry naturnomu vyprobuvanni na vtomlenist [Research of the stages of nucleation and growth of cracks in fullscale tests on fatigue]. Visnyk Dnipropetrovskoho natsionalnoho universytetu zaliznychnoho transportu [Bulletin of Dnipropetrovsk National University of Railway Transport], 2008, issue 21, pp. 266-268.

9. Kottrell A.Kh. Dislokatsii i plasticheskoye techeniye v kristallakh [Dislocations and plastic flow in crystals]. Moscow, Metallurgizdat Publ., 1958. 255 p.

10. Nott Dzh. Osnovy mekhaniki razrusheniya [Foundations of the fracture mechanics]. Moscow, Metallurgiya Publ., 1978. $256 \mathrm{p}$.

11. Atkinson J.D. The Work - hardening of Copper - Silica: IV. The Bauschinger Effect and Plastic Relaxation. Philosophical Magazine, 1974, vol. 30, no. 6, pp. 1247-1280.

12. Crist B.W. Comparison of the Hall - Petch parameters of Zone - refined Iron Determined by the Grain Size and Extrapolation Methods. Acta Metallurgica, 1967, vol. 15, no. 5, pp. 809-816.

13. Garofalo F. Factors Affecting the Propagation of a Luders Band and the Lower Yield and Flow Stressers. Metallurgical Transactions, 1971, vol. 2, no. 8, pp. 2315-2317.

14. Gleiter H., Chalmers B. High - Grain Boundaries. Progress in Materials Science, 1972, vol. 16, 375 p.

15. Hollomon John H. Tensile Deformation. AIME, 1945, vol. 162, pp. 268-290.

16. Holzman M., Man J. Determination of Friction stress in BCC polycristalls. Journal of the Iron and Steel Institute, 1966, vol. 204, no. 3, pp. 230-234.

17. Vakulenko I.A, Perkov O.N., Razdobreyev V.G. Mechanism of the Effect of the Ferrite Grain Size on the Fatigue Strength of a Low - Carbon Steel. Russian Metallurgy, 2008, vol. 2008, no. 3, pp. 225-228.

Associate Professor L. I. Kotova, Ph.D. (Tech); Associate Professor O. A. Chaykovskiy, Ph.D. (Tech) recommended this article to be published

Received: Nov. 11, 2013

Accepted: Jan. 14, 2014 